\title{
LEADERSHIP IN TIME OF CRISIS: THE COVID-19 PANDEMIC IN JAPAN AND REFLECTIONS FOR MALAYSIA
}

\begin{abstract}
Muhammad Danial Azman ${ }^{1}$, Asmadi Hassan ${ }^{2}$
The 2019 Coronavirus (COVID-19) outbreak was one of the most massive pandemics in history, with over 29.6 million people infected, including over 400,000 cases in Japan. This article describes the leadership tasks in a time of crisis during the different stages of Japan's COVID-19 strategy under Shinzo Abe and Yoshihide Suga's leadership. Our aim is to formulate lessons from Japan for Malaysia. Shallow assessments of leadership performance often accompany the deeply rooted belief in the importance of political leadership. Such reviews never arrive more quickly than in the wake of crises - dramatic disasters of COVID-19 cases and Abe's resignation from the prime minister post. While symbolic performance is necessary (if only because it can arouse the public), it is one of the plausible avenues for the public to express their political judgements upon leadership in a time of crisis. In this article, we adopted a qualitative methods of library research and highlights on the many expected tasks of Japanese prime ministers to perform, and we offer a lesson for Malaysia in times of crisis.
\end{abstract}

Keywords: Pandemic as a political crisis, leadership, lessons in public policy, Malaysia

\section{INTRODUCTION}

The Corona Virus (COVID-19) pandemic outbreaks from Wuhan, China, have infected more than 92 million people now with 1.9 million fatalities. ${ }^{3}$ In Japan, 400,000 people were infected while 7000 people have died. ${ }^{4}$ Being one of the deadly pandemics of this century, governments across the globe made various efforts to contain the disease, including the infamous total lockdown in Wuhan, China, various tiers of travel restrictions, and even measures of Movement Control Order (MCO). ${ }^{5}$ Thus, this spark multiple debates about policies and counter measures enacted by governments and international coordination among states in accelerating the development of vaccine production. ${ }^{6}$ In short, COVID19 "is a political problem as much as it is a public health tragedy" ${ }^{7}$. However often, politics is presented

\footnotetext{
${ }^{1}$ Corresponding Author: Senior Lecturer, Faculty of Arts and Social Sciences, University of Malaya, Malaysia. Email: danial@um.edu.my.

${ }^{2}$ Senior Lecturer, Department of East Asian Studies, Faculty of Arts and Social Sciences, University of Malaya, Malaysia. Email: madisan@um.edu.my.

${ }^{3}$ World Health Organization (WHO), COVID-19 Weekly Epidemiological Update, WHO, 28 February, 2021, available at: https://covid19.who.int/, accessed on 1 March, 2021.

${ }^{4}$ World Health Organization (WHO), Japan: WHO Coronavirus Disease (COVID-19) Dashboard, WHO, 3 March, 2021, available at: https://covid19.who.int/region/wpro/country/jp, accessed on 1 March 2021.

5 Rishi R. Parajuli, Bhogendra Mishra, Amrit Banstola, et al. "Multidisciplinary Approach to COVID-19 Risk Communication: A Framework and Tool for Individual and Regional Risk Assessment," Scientific Reports, Vol. 10, No. 1, 2020, p.3.

${ }^{6}$ Matthew Flinders, "Democracy and the Politics of Coronavirus: Trust, Blame and Understanding," Parliamentary Affairs, Vol. 0, 2020, p. 2.

${ }^{7}$ Sara E. Davies and Clare Wenham, "Why the COVID-19 Response Needs International Relations," International Affairs, Vol. 96, No. 5, 2020, p. 1227.
} 
as an ignoble irritant in contrast to the public health domain. This was truer than ever when considering Japan as one of the earliest countries in dealing with the pandemic and subsequent recovery measures served as a reminder to other countries.

Subsequent discussions and sections of this article unravel Japan as an instructive case study. Drawing from secondary and recent literature published about COVID-19 and Japan, we argue that politics is deciding how COVID-19 is spreading and whether polices enforced is a pretext not to elevate public health. As it is clear from the different Japanese government responses to the outbreak itself, technical decisions require political verdicts about who should be consulted, who should provide advice, and which models should be used. The government's political decisions include declaring an emergency or total lockdown and the ramification of such calculative directives upon existing woes and problems of the citizens, especially during the initial post-recovery phase of people's livelihood and ongoing economic recessions in Japan. ${ }^{8}$ This article will is divided into three main parts. The first part explores a framework to understand political leadership roles in crisis time, which serve to examine political decisions. The focus will be based on the last 12-months of the pandemic and political decisions by the previous Prime Minister Shinzo Abe (January-August 2020) and recently appointed Yoshihide Suga (September 2020-January 2021). It will be beyond this article's scope to illuminate a complete political analysis of all decisions and public opinions of the Japanese society. The focus will be brief and mostly upon the initial transitions of both leaders and the consequences of the government's action in curving the outbreaks, and initiating the recovery phase. The second part discusses the reflections of Japan in dealing with the pandemic's scale upon public health and public confidence in political leadership. The third section highlights important lessons on the appropriateness of transferring Japan's model to our country, Malaysia. In conclusion, our findings suggest the need to acknowledge a political nexus between the health pandemic and democratic crisis when exploring public views upon leadership performance.

\section{THE FRAMEWORK OF ASSESSMENT: LEADERSHIP IN TIME OF CRISIS}

In learning lessons from Japan, one thing that is clear is that policy implementation in time of pandemic turbulence must adapt and respond to its environment. The existing literature of leadership in crisis management of the public health policy is often inspired by the Caplan's crisis theorical assumption. ${ }^{9}$ Reflections must draw on previous loss and challenge as society seeks a solution of the way out from the current pandemic crisis. ${ }^{10}$ Thus, a crisis is regarded as an urgent situation that requires immediate and decisive action by the leaders. ${ }^{11}$ Understanding a pandemic as a political crisis is essential in acknowledging the perception of an unpredictable event that threatens taxpayers' important expectancies. Inevitably, they may seriously impact the wellbeing of the stakeholders' and leaders' performative functions through negative outcomes. ${ }^{12}$ Through comprehensive studies of leadership traits among the head of the governments of selected countries who are profoundly affected by previous Middle East Respiratory Syndrome of Coronavirus (MERS) pandemic, researchers ${ }^{13}$ identified five pandemic features as a political crisis. Accordingly, irrespective of the nature of the state and political community in which the pandemic erupted: firstly, pandemic involves a wide range

\footnotetext{
${ }^{8}$ M. Uehara, M. Fuji, and K. Kobayashi, "A Model of Stress Change under the First COVID-19 Pandemic among the General Public in Japanese Major Cities and Rural Areas, Sustainability,”Vol. 13, No. 3, 2021, p. 15.

${ }^{9}$ See G. Caplan, Principles of Preventive Psychiatry, New York: Basic Books, 1964.

${ }^{10}$ Editor. "Unprecedented Times? Social Work and Society post-COVID-19," British Journal of Social Work, Vol. 50, 2020, p. 1298.

${ }^{11}$ Francois Gerard, "Clement Imbert and Kate Orkin, Social Protection Response to the COVID-19 Crisis: Options for Developing Countries," Oxford Review of Economic Policy, Vol. 31, No. 1, 2020, p. 283.

12 Valentina Giammaria, “COVID-19 in Japan: A Nightmare Disease, Asia Pacific Journal-Japan Focus, ” Vol. 18, No. 18, 2020, p. 4.

${ }^{13}$ Mia R. K. Hartmann and Rasmus Koss Hartmann, "Frontline Innovation in Times of Crisis: Learning from the Corona Virus Pandemic,” Policing, Vol. 14, No. 4, 2020, p. 1093.
} 
of stakeholders; secondly, time pressures are require an urgent response; thirdly, there is usually little if any warning to the leader; fourthly, there is a high degree of ambiguity in which causes and effects are unclear; and finally, they create a significant threat of disruption to the leader's performative function in the society. ${ }^{14}$ Drawing based on past experiences among the East Asian, African, and Scandinavian countries when dealing with a health crisis, Gilson highlights the catastrophic experiences of health officers and frontliners during the apex of the pandemic. ${ }^{15}$ This happens when political leaders cannot comprehend the priority of saving citizens' lives instead of instrumentalizing health care facilities for their immediate needs of political rhetoric.

In this regard, the former Ministry of Health of Liberia, Tolbert Nyensway highlights the vitality of learning from leaders' past mistakes when dealing with the 2014 Ebola outbreaks. ${ }^{16}$ In his reflections, he highlights six key principles of crisis leadership: firstly, there is no substitute for political leadership; secondly, for the leader to effectively lead the country during the challenging moment, there must be two-way communication with the subordinate and health experts; thirdly, the imperative roles of the government to take ownership of the crisis-response mechanisms; fourthly, the state leader must emphasize a function of the delivery system and structure at the early sequence of the crisis; fifthly, the importance of healthy relations and networks with international partners in datasharing and subsequent vaccination development programme; and finally, quality of well-respected leadership comes from the most challenging time which provide opportunities for the public to form a cohesive opinion. ${ }^{17}$ Given the inherent nature of the pandemic and state disruptions faced by political leaders, we argue that the past lessons from dealing with the Ebola pandemic based on these six principles could be regarded as a framework in examining the performative quality of leadership in a time of health crisis in Japan. A critical appraisal of the Japanese political leadership and their performative functions will be highlighted in the subsequent sections.

\section{THE COVID-19 PANDEMIC IN JAPAN AND WAVES OF OUTBREAKS}

The outbreak of the COVID-19 pandemic in Japan is related to the ongoing global covid phenomenon caused by similar severe acute respiratory syndrome coronavirus 2 (SARS-Cov-2) that have occurred in other countries and as reported by the World Health Organization (WHO) ${ }^{18}$ The first confirmed case of the pandemic was recorded on January 16, 2020, by a Kanagawa resident who had previously returned from Wuhan, China. This is regarded as the first wave of the pandemic and later, followed by the second wave when a few Japanese who travelled and returned from several European countries and the United States confirmed to have the same virus strain between 11 and 23 March $2020 .{ }^{19}$ As reported by the National Institute of Infectious Disease (NIID), most of the nationwide pandemic outbreaks and spread patterns are more pervasive among those infected by the second wave since the first wave that originated from Wuhan have been subdued by the end of March $2020 .{ }^{20}$ By October 5, 2020, a total number of positive cases in Japan crossed more than 100,000 cases and exceeded the

\footnotetext{
${ }^{14}$ Hartmann and Hartmann, "Frontline Innovation in Times of Crisis," Ibid., p. 1094.

${ }^{15}$ Lucy Gilson, "Everyday Politics and the Leadership of Health Policy Implementation," Health Systems \& Reform, Vol. 2, No. 3, 2016, p. 189.

16 Tolbert Nyenswah, "Leadership in Times of Crisis: A Personal Reflection from the Center of the Ebola Epidemic Response in Liberia," Health Systems \& Reform, Vol. 2, No. 3, 2016, p. 211.

${ }^{17}$ Nyenswah, "Leadership in Times of Crisis," Ibid., p. 212.

${ }^{18}$ World Health Organization (WHO), Japan: WHO Coronavirus Disease (COVID-19) Dashboard, WHO, 3 March, 2021, available at: https://covid19.who.int/region/wpro/country/ip, accessed on 1 March, 2021.

${ }^{19}$ Yoko Konishi, Takashi Saito, Toshiki Ishikawa, et al. How did Japan Cope with COVID-19? Big Data and Purchasing Behaviour, Asian Economic Papers, Vol. 2, No. 1, 2016, p. 37.

${ }^{20}$ National Institute of Infectious Disease (NIID), "Descriptive Epidemiology of 12 Confirmed Cases in Japan", NIID, 3 February, 2020, available at: https://www.niid.go.jp/niid/en/2019-ncov-e/2488-idsc/iasr-news/9400-481pe01.html, accessed on 1 March, 2021.
} 
confirmed cases in nationwide China. ${ }^{21}$ By the end of December 2020, Japan reported 230,000 positive-cases, and this number further increased to 400,000 cases in February 2021.22 Official statistic issued by the Ministry of Health, Labour and Welfare reported a total number of 7,860 deaths and 409,319 recovered cases from the COVID-19 pandemic by early February 2021. The reported death in Japan exceeded the total number of deaths in China.

Initially, this was the significant concern of the former Prime Minister Shinzo Abe and the newly created, Japan Anti-Coronavirus National Task Force (ACNTF), especially given the vast numbers of ageing populations in Japan when compared to other Organizations for Economic Cooperation and Development (OECD) countries. Despite the alarming trend in confirmed cases and reported deaths, Japan's fatality rate per capita from COVID-19 is the lowest among the developed countries. ${ }^{23}$ The early literature on comparative assessments between Japan and the US in managing public health crisis hasshown better and more effective measures undertaken by Japan compared to drastic increments of positive and death cases in the US under President Donald Trump's failure administration. ${ }^{24}$ Nonetheless, the initial speedy and reactive measures initiated by Shinzo Abe have shown a better performance by Japan when compared to the US despite contending challenges of dealing with the ageing population. The discussions next details public health policy and emergency measures undertaken by former Abe and the current Prime Minister Yoshihide Suga.

\section{RESPONDING TO THE PUBLIC OUTCRIES: PANDEMIC AS POLITICAL CRISIS}

The Shinzo Abe administration has adopted various measures to contain and break the transmission chain of the infection. During the first and second quarter of 2020, Japan is regarded as a viable model in dealing with the pandemic. On January 30th 2020, Abe established the ACNTF to coordinate the government's health responses to the pandemic. Nevertheless, specific responses can be divided as follows:

\section{Phase One: Containment and Travel Restriction Measures}

During the periods between January and February 2020, the government's initial response was a policy of containment and focused on the repatriation of Japanese citizens from Wuhan and other parts of China. In responding to the first announcement made by the Director-General of the WHO, Tedros Adhanom, on confirming human-to-human transmissions of COVID-19, on January $24^{\text {th }}, 2020$, Shinzo Abe convened the ministerial-level meetings, and with coordination of NIID, he announced countermeasures. ${ }^{25}$ By January $27^{\text {th }}, 2020$, Abe announced his administration priority in perceiving and equating the "infectious disease" as a political crisis under the Infectious Diseases Law which

\footnotetext{
${ }^{21}$ Lisa Schnirring, Japan has 1st Novel Coronavirus Case, Center for Infectious Disease Research and Policy, 16 January, 2020, available at: https://www.cidrap.umn.edu/news-perspective/2020/01/japan-has-1st-novel-coronavirus-case-chinareports-another-death, accessed on 1 March, 2021.

22 Statista, "Cumulative Number of Patients Diagnosed with Coronavirus Disease (COVID-19) in Japan", Statista, 15 January, 2021, available at: https://www.statista.com/statistics/1096478/japan-confirmed-cases-of-coronavirus-by-stateof-health/, accessed on 1 March, 2021.

${ }^{23}$ Haiqian Chen, Leiyu Shi, Yuyao Zhang, et al. "A Cross-Country Core Strategy Comparison in China, Japan, Singapore and South Korea during the Early COVID-19 Pandemic,” Globalization and Health, Vol. 17, No. 1, 2021 , p. 4.

${ }^{24}$ Carla Norrlof, "Is COVID-19 the end of US Hegemony? Public Bads, Leadership Failures and Monetary Hegemony," International Affairs, Vol. 96, No. 5, 2020, p. 1285.

25 The New York Times (NYT), The Illness Now Has a Name, COVID-19, NYT, 11 February, 2020, available at: https://www.nytimes.com/2020/02/11/world/asia/coronavirus-china.html?searchResultPosition=8, accessed on $1 \mathrm{March}$, 2021.
} 
provides extraordinary authorizations to enforce positive covid patients to undergo hospitalization. ${ }^{26}$ Simultaneously, the government enforced the Quarantine Act, which allows the mandatory quarantine of suspected people and orders them to undergo further tests and treatments. ${ }^{27}$ On January $30^{\text {th }}, 2020$, Response Headquarters and a task force led by the Deputy Chief Cabinet Secretary for Crisis Management, Okita Yoshiki was created. ${ }^{28}$ Between January $31^{\text {st }}$, and February $17^{\text {th }}$, 2020, Abe announced the importance of repatriation of Japanese nationals in the province of Huaibei, China,through several negotiated agreements and dispatch-chartered flights with the Chinese authority. ${ }^{29}$ By the early weeks of February 2020, several measures of travel restrictions were enacted. This includes restrictions to deny entry to foreigners who have previously visited the Huaibei province, those with Chinese passport, and those with previous travel histories to China. The invocation of the Quarantine Act escalated the measures to stop the movement of the Diamond Princess cruise ship in Yokohama, where health officers were dispatched to prevent the disembarkation of crew and passengers from landing in Japan. ${ }^{30}$ A similar incident occurred on February $6^{\text {th }}, 2020$ when the MS Westerdam cruise from Hong Kong was quarantine after reported news about a number of passengers who tested positive for the virus. Given the early focus on containment measures, Abe's administration realized the political needs of centralizing coordination measures in testing and quarantine, which will be discussed next.

\section{Phase Two: Coordinated Testing Centre}

The containment measures are not only limited to the foreign nationals' travel restriction to Japan, but followed by subsequent reinforcement of the medical service system. Since the COVID-19 outbreak on the cruise ship Diamond Princess, the Japanese government shifted its focus from a policy of containment to prevention and treatment because they anticipated an increasing community spread within Japan. This policy prioritized creating a testing and consultation system based on the prescriptions by the NIID and the 83 existing municipal and prefectural public health institutions that are separate from the civilian hospital system. ${ }^{31}$ The new system handles the transfer of patients to mainstream medical facilities to facilitate patient flow, triage, and the management of limited testing kits on their behalf to prevent a rush of infected and uninfected patients from overwhelming healthcare providers and transmitting diseases to them. ${ }^{32}$ By regulating COVID-19 testing at the national level, the Abe Administration integrated the national government's activities, local governments, medical professionals, business operators, and the public in treating the disease.

${ }^{26}$ Ben Dooley, Shinzo Abe, Japan's Political Houdini, Can’t Escape Coronavirus Backlash, The New York Times, 10 March, 2020, available at: https://www.nytimes.com/2020/03/05/world/asia/japan-abe-coronavirus.html, accessed on 1 March, 2021.

${ }^{27}$ Motoko Rich, We're in a Petri Dish: How a Coronavirus Ravaged a Cruise Ship, The New York Times, 23 February 2020, available at: https://www.nytimes.com/2020/02/22/world/asia/coronavirus-japan-cruise-ship.html, accessed on 1 March, 2021.

${ }^{28}$ Satoshi Sugiyama, Japan Coronavirus Task Force may Set Stage of Emergency, The Japan Times, 26 March, 2020 , available at: https://www.japantimes.co.jp/news/2020/03/26/national/science-health/japan-coronavirus-task-force/, accessed on 1 March, 2021.

${ }^{29}$ Matteo Chinazzi, Jessica T. Davis, Marco Ajelli, et al. The Effect of Travel Restrictions on the Spread of the 2019 Novel Coronavirus (COVID-19) Outbreak, Science, Vol. 368, No. 6489, 2020, p. 398.

${ }^{30} \mathrm{Jiji}$, Abe Reluctant to Head Calls for Coronavirus Law Revisions, The Japan Times, 3 August, 2020, available at: https://www.japantimes.co.jp/news/2020/08/03/national/politics-diplomacy/japan-shinzo-abe-coronavirus-law/, accessed on 1 March, 2021.

${ }^{31}$ National Institute of Infectious Disease (NIID), Descriptive Epidemiology of 12 Confirmed Cases in Japan, NIID, 3 February, 2020, available at: https://www.niid.go.jp/niid/en/2019-ncov-e/2488-idsc/iasr-news/9400-481pe01.html, accessed on 1 March, 2021.

32 Syed Mahfuz Al hasan, Jennifer Saulam, Kanae Kanda, et al. "Trends in COVID-19 Outbreak in Tokyo and Osaka from January 25 to May 6 2020: A Joinpoint Regression Analysis of the Outbreak Data," Japanese Journal of Infectious Disease, Vol. 74, No. 1, 2021 , p. 374. 
On February $1^{\text {st }}, 2020$, the Ministry of Health, Labour and Welfare instructed prefectural governments to establish specialized consultation hubs and outpatient wards at their local public health facilities. ${ }^{33}$ Such wards provide medical examinations and testing for suspected disease carriers to protect general hospitals from infection. On February $5^{\text {th }}, 2020$, Abe announced that the government would begin preparations to strengthen testing capabilities at the NIID and 83 municipal and prefectural public health institutions that the government designates as official testing sites ${ }^{34}$ Without a uniform diagnosis kit for the disease, the government has relied on Polymerase Chain Reaction (PCR) tests to check for infections. As few major medical facilities in Japan can conduct PCR tests, Abe initially promised to increase the number of premises with such kits, including universities and companies. ${ }^{35}$ On February $12^{\text {th }}, 2020$, Abe announced that the government would expand the scope of testing to include patients with symptoms based on local governments' discretion. ${ }^{36}$ Previously, testing was restricted to those with a history of travelling to the Huaibei province. On the same day, the Ministry of Health, Labour, and Welfare and NIID contracted SRL Inc to handle PCR clinical laboratory testing. ${ }^{37}$ Since then, the government has partnered with additional private companies to expand laboratory testing capabilities and work towards developing a rapid testing kit. This eventually leads to the introduction of the government's controlled centre for a consultation, testing and public response upon covid. The Prime Minister's Office initiated the first ministerial-level meeting that assembles the country's top health and disease experts on February $16^{\text {th }}$, $2020 .{ }^{38}$ During the meeting, the Director of the NIID Dr. Wakita Takaji, raised the public concern about the overcrowded hospital by uninfected persons and those with mild symptoms. ${ }^{39}$ However, some of the Abe administration cabinet members believed that the current measures should be adequate. There is no need to create public's panic by overreacting to the issues. ${ }^{40}$ This political advise was later rejected by most of the top health experts who joined that meeting. They emphasized the unintended consequence of unseparated medical facilities among positive patients and persons under investigations (PUI) and existing uninfected patients, resulting in strained availability of medical resources to coup with both covid and non-covic cases simultaneously. ${ }^{41}$

33 Atsuna Tokumoto, Hiroki Akaba, Hitoshi Oshitani, et al. COVID-19 Health System Response Monitor: Japan, Asia Pacific Observatory on Health Systems and Policies, 28 January, 2021, available at: https://apps.who.int/iris/bitstream/handle/10665/338399/9789290228264-eng.pdf, accessed on 1 March, 2021.

34 Ben Dooley, Shinzo Abe, Japan's Political Houdini, Can't Escape Coronavirus Backlash, The New York Times, 10 March, 2020, available at: https://www.nytimes.com/2020/03/05/world/asia/japan-abe-coronavirus.html, accessed on 1 March, 2021

${ }^{35}$ Ben Dooley and Makiko Inoue, Testing Key to Beating Coronavirus, Right? Japan Has Other Ideas, The New York Times, 28 August, 2020, available at: https://www.nytimes.com/2020/05/29/world/asia/japancoronavirus.html?searchResultPosition=3, accessed on 1 March, 2021.

${ }^{36}$ Eric A. Fieldman, Did Japan's Lenient Lockdown Conquer the Coronavirus?, The Regulatory Review, 10 June, 2020 , available at: https://www.theregreview.org/2020/06/10/feldman-japan-lenient-lockdown-conquer-coronavirus/, accessed on 1 March, 2021.

37 Junichi Oshita, As Japan Lags in Coronavirus Tests, Companies too Triple Capacity, Nikkei Asia, 30 May, 2020, available at: https://asia.nikkei.com/Spotlight/Coronavirus/As-Japan-lags-in-coronavirus-tests-companies-to-triplecapacity

, accessed on 1 March, 2021.

${ }^{38}$ Isabella Steger, Japan Finally decided to Hold a Virtual Cabinet Meeting as a Coronavirus Precaution, Quartz, 31 May, 2020, available at: https://qz.com/1849256/japan-cabinet-finally-holds-first-virtual-meeting-during-coronavirus/, accessed on 1 March, 2021.

${ }^{39}$ Kyodo, Experts Warn of Healthcare Collapse in Japan if Virus Keeps Spreading”, The Japan Times, 2 April, 2020 , available at: https://www.japantimes.co.jp/news/2020/04/02/national/health-care-collapse-warning-japan-coronavirus/, accessed on 1 March, 2021.

${ }^{40}$ Vivian Wang, As Death Mounts, Governments Point Fingers Over Coronavirus, The New York Times, 6 March, 2020, available at: https://www.nytimes.com/2020/03/06/world/coronavirus-world.html?searchResultPosition=7, accessed on 1 March, 2021.

${ }^{41}$ Reuters Staff, Japan to Disband Panel of Coronavirus Experts after Criticism, Reuters, 25 June, 2020, available at: https://www.reuters.com/article/us-health-coronavirus-japan-panel-idUSKBN23W0UY, accessed on 1 March, 2021. 
On February $17^{\text {th }}, 2020$, the Ministry of Health released a national blueprint for COVID-19 testing to all local governments and public health officers based on two initial directives. ${ }^{42}$ Firstly, instructions on limiting consultations with patients who recorded cold symptoms and temperature reading beyond $37.5^{\circ} \mathrm{C}$. Secondly, patients with extreme fatigue and respiratory problems. However, these directives will consider some exceptions for pre-existing older people and pregnant women with cold symptoms so these vulnerable populations can be targeted immediately. Given the public concern about increasing numbers of in-community infections which originated from the first wave of Wuhan in Kanagawa, Abe administration approved the use of favipiravir, an anti-influenza medication to treat sting covid patients. ${ }^{43}$ The announcements were met with public criticisms ${ }^{44}$ instantly and further pushed the government to quickly draft a more comprehensive covid plan.

\section{Phase Three: National Mitigation Strategy}

On February 23rd 2020 , Abe instructed the government's coronavirus task force to draft a comprehensive basic policy quickly. ${ }^{45}$ The Health Minister, Katsunobu Katō reconvened the medical experts from the first Novel Coronavirus Expert Meeting to draft this policy. ${ }^{46}$ During the meeting, the medical establishment presented its policy recommendations in the form of a view, concluding that the most important objective must be to prevent large-scale disease clusters and a decrease in outbreaks and deaths. They stated that it would not be possible to prevent the spread of COVID-19 in Japan on a person-to-person basis, but it might be possible to regulate the overall speed of infection. ${ }^{47}$ In a nutshell, this meeting confirmed that time is a critical factor when dealing with pandemics and infectious lines. Interestingly, it was evident during the meeting that Japan is learning from past experiences of other countries when dealing with Japanese Encephalitis (JE), Severe Acute Respiratory Syndrome (SARS), Ebola, and Middle East Respiratory Syndrome of Coronavirus (MERS-CoV) outbreaks, especially on whether the country would experience a large cluster that could result in the collapse of the medical system and socio-economic disruptions. ${ }^{48}$ After reviewing and discussing the existing data on the disease, the committee stated that universal PCR testing was impossible due to a shortage of testing facilities and recommended that the government instead limit the application of available test kits to patients that are at a high risk of complications to stockpile for a large cluster. ${ }^{49}$ Participants also noted that Japan's medical facilities are vulnerable to "chaos", noting that many hospital beds and resources in the Tokyo area were already being used to care for the 700 infected

\footnotetext{
${ }^{42}$ Nikkei Staff Writers, Japan's Coronavirus Testing behind the Curve, Abe Admits, Nikkei Asia, 5 May, 2020, available at: https://asia.nikkei.com/Spotlight/Coronavirus/Japan-s-coronavirus-testing-behind-the-curve-Abe-admits, accessed on 1 March, 2021.

43 Isabel Ryenolds, Japan's Abe Follows Trump in Fast Drug Approvals After Criticism, Bloomberg, 12 May, 2020, available at: https://www.bloomberg.com/news/articles/2020-05-11/japan-s-abe-follows-trump-in-fast-drug-approvalsafter-criticism, accessed on 1 March, 2021.

${ }^{44}$ Linda Sieg, Where's Abe? Critics Ask, as Coronavirus Spreads in Japan, Reuters, 25 February, 2020, available at: https://www.reuters.com/article/us-china-health-japan-abe-idUSKCN20J16F, accessed on 1 March, 2021.

${ }^{45}$ Daisuke Akimoto, COVID-19 and Japan's Global Health Strategy: Developing Vaccines in a Human Security Crisis, Institute for Security \& Development Policy, 6 May, 2020, available at: https://isdp.eu/covid-19-japans-global-healthstrategy/, accessed on 1 March, 2021.

${ }^{46}$ YHY, Japan's Abe Orders Gov't to Draft Policy to Fight COVID-19, Xinhua News, 23 February, 2020, available at: http://www.xinhuanet.com/english/2020-02/23/c 138811067.htm, accessed on 1 March, 2021.

${ }^{47}$ Kimimasa Mayama, How Shinzo Abe has Fumbled Japan's Coronavirus Response, The Conversation, 27 April, 2020, available at: https://theconversation.com/how-shinzo-abe-has-fumbled-japans-coronavirus-response-136860, accessed on 1 March, 2021.

${ }^{48}$ Shimizu Kazuki and Negita Masashi, "Lessons Learned from Japan's Response to the First Wave of COVID-19: A Content Analysis," Healthcare, Vol. 8, No. 4, 2021, p. 2.

${ }^{49}$ Ai Tashiro, and Rajib Shaw, "COVID-19 Pandemic Response in Japan: What is Behind Flattening of the Curve?," Sustainability, Vol. 12, No. 3, 2020, p. 4.
} 
patients from the Diamond Princess..$^{50}$ They reiterated their warning that a rush of alarmed, uninfected outpatients with light symptoms of the disease could overwhelm hospitals and turn waiting rooms into "breeding grounds" for COVID-19.51

Nevertheless, On February $25^{\text {th }}, 2020$, Abe took note on the spike of infections in Italy, Iran and South Korea and introduced a policy to "flatten the curve". ${ }^{52}$ Abe decided that the government's disease countermeasures would prioritize the prevention of large-scale clusters in Japan. This included controversial requests to suspend large-scale gatherings such as community events and school operations and limit patients with light cold symptoms from visiting medical facilities to prevent them from overwhelming hospital resources. There are three major strategies of this policy: (1) to se advise citizens with mild cold-symptoms to rely on bed rest at home rather than seek medical help from clinics or hospitals. Meanwhile, those with high risk of infections, the elderly and pre-existing sickness are encouraged to stay away from the hospital and should order prescriptions over the telephone instead of in person; (2) to allow general medical facilities in areas of rapid COVID-19 outbreak to accept patients suspected of infection; and finally, (3) to encourage citizens with any cold symptoms to apply for a leave from work and avoid leaving their home. ${ }^{53}$ Government officials urged companies to let employees work from home and commute at off-peak hours. The Japanese government also made an official request to local governments and businesses to cancel large-scale face-to-face events.

In ensuring the implementation of this policy, Abe requested all schools' closure from March $2^{\text {nd }}, 2020$ to the end of spring vacations, which usually conclude in early April. ${ }^{54}$ The next day, the Japanese government announced plans to create a fund to help companies subsidize workers who need to take days off to look after their children while schools are closed. On February $27^{\text {th }}, 2020$, the government also announced plans to expand the national health insurance system to cover covid test costs. ${ }^{55}$ Yet, on March $9^{\text {th }}$, 2020, the Ministry of Health reconvened the Expert Meeting after the two weeks "critical moment", and they concluded that Japan was currently not on track to experience a large-scale cluster, but stated that there is a two-week time lag in analyzing COVID-19 trends, resulting in subsequent rising numbers in daily infections. ${ }^{56}$ Consequently, the participants asked the government to remain vigilant in quickly identifying and containing smaller clusters. Despite the warning made by the expert meeting committee, the slow response made by Abe's administration resulted in more uncontrolled infection chains from the second waves of Europe and the United States. ${ }^{57}$ This eventually pushed the Ministry to publish a daily disease forecast for each prefecture and instructed local governments to prepare their hospitals to accommodate their patient estimates. By then, alarming reported ${ }^{58}$ cases in Tokyo and Hokkaido became a primary reason for Abe to consider a similar lockdown measure as done in China.

\footnotetext{
${ }^{50}$ Shimizu Kazuki and Negita Masashi, "Lessons Learned from Japan's Response to the First Wave of COVID-19: A Content Analysis," Ibid., p. 4.

${ }^{51}$ Ibid., p. 5.

${ }^{52}$ Ai Tashiro, and Rajib Shaw, COVID-19 Pandemic Response in Japan: What is Behind Flattening of the Curve?" Ibid., p. 9.

${ }^{53}$ Ibid., p. 10.

${ }^{54}$ Motoko Rich, Ben Dooley, and Makiko Inoue, Japan Shocks Parents by Moving to Close All Schools Over Coronavirus, The New York Times, 27 February, 2020, Available at: https://www.nytimes.com/2020/02/27/world/asia/japan-schoolscoronavirus.html?searchResultPosition=4, accessed on 1 March, 2021.

55 Julian Ryall, Coronavirus: Japan's Employees are Working From Home, but Stress has Followed Them, The South China Morning Press, 13 April, 2020, Available at: https://www.scmp.com/week-asia/healthenvironment/article/3079646/coronavirus-japans-employees-are-working-home-stress, accessed on 1 March, 2021.

${ }^{56}$ BBC Writers, Coronavirus: Japan Doctors Warn of Health System 'Break Down' as Cases Surge, BBC, 18 April, 2020 , Available at: https://www.scmp.com/week-asia/health-environment/article/3079646/coronavirus-japans-employees-areworking-home-stress, accessed on 1 March, 2021.

${ }^{57}$ Sho Saito, Yusuke Asai, Nobuaki Matsunaga, et al. "First and Second COVID-19 Waves in Japan: A Comparison of Disease Severity and Characteristics", Journal of Infection, Vol. November, 2020, p. 17.

${ }^{58}$ Hasan, Saulam, Kanda, et al. "Trends in COVID-19 Outbreak in Tokyo and Osaka from January 25 to May 62020 ", Ibid., p. 376.
} 


\section{Phase Four: Proclamation Of Emergency}

On February $5^{\text {th }}, 2020$, the Abe's administration coronavirus task force initiated a parliamentary debate on introducing emergency measures to combat the outbreak a day after the Diamond Princess ship was asked to quarantine. ${ }^{59}$ The initial debate focused on constitutional reform due to the task force's apprehension that the Japanese Constitution may restrict the government's ability to enact such compulsory measures as quarantines because it violates human rights. After lawmakers representing almost all political parties voiced their strong opposition towards this proposal and asserted that the constitution allowed for emergency measures, the Abe administration moved forward with legislative reform instead. ${ }^{60}$ On March $5^{\text {th }}, 2020$, Abe introduced a draft amendment to the existing Special Measures Act to Counter New Types of Influenza of 2012 to extend the law's emergency measures with the inclusion of ongoing COVID-19. ${ }^{61} \mathrm{He}$ met separately with the heads of five opposition parties on March $4^{\text {th }}, 2020$ to promote a "united front" in passing the reforms, and the amendment was passed on March $13^{\text {th }} 2020$, making it effective for the next two years. ${ }^{62}$

The amendment allows Abe to declare a state of emergency in specific areas where COVID19 poses a grave threat to residents' lives and economic livelihood. During such a period, governors of affected areas will receive the following powers: (1) to instruct residents to avoid unnecessary outings unless they are workers in such essential services like health care and public transportation; (2) to restrict the use or request the temporary closure of businesses and facilities, including schools, social welfare facilities, theatres, music venues, and sports stadiums; (3) to expropriate private land and buildings to erect new hospitals; and (4) to request medical supplies and food from companies that refuse to sell them, punish those that hoard or do not comply, and force firms to help transport emergency goods. ${ }^{63}$ Under the law, the Japanese government does not have the authority to enforce citywide lockdowns. Apart from individual quarantine measures, officials cannot restrict the movement of people to contain the virus. Consequently, compliance with government requests to restrict movements is rather based on "asking for public cooperation to 'protect people's lives and minimize further damage to [the economy]". 64

By March $25^{\text {th }}, 2020$, the Ministry of Health, Labour and Welfare announced the drastic increases of positive cases in Tokyo. ad On March $26^{\text {th }}, 2020$, an expert meeting at the ministerial level confirmed the worse nightmare of "high probability of an expansion of infections" within the country due to an increase in the number of infected patients returning from Europe and the United States between $11^{\text {th }}$ March 2020 and $23^{\text {rd }}$ March $2020 .{ }^{65}$ In response to the statement, Abe instructed the Economic Policy Minister, Yasutoshi Nishimura to establish a special government task force to

59 Editor, Japan Declares State of Emergency Over Coronavirus, The Guardian, 7 April, 2020, available at: https://www.theguardian.com/world/2020/apr/07/japan-shinzo-abe-declares-state-of-emergency-over-coronavirus, accessed on 1 March, 2021.

${ }^{60}$ Takashi Yoshioka, and Yohei Maeda, "COVID-19 Stigma Induced by Local Government and Media Reporting in Japan: It's Time to Reconsider Risk Communication Lessons From the Fukushima Daiichi Nuclear Disaster", Journal of Epidemiology, Vol. 30, No. 8, 2020, p. 372.

${ }^{61}$ Will Repley, There are Fears a Coronavirus Crisis Looms in Tokyo. Is It Too Late to Change Course?, CNN, 4 April, 2020, available at: https://edition.cnn.com/2020/04/03/asia/tokyo-coronavirus-japan-hnk-intl/index.html, accessed on 1 March, 2021.

62 Asahi Writers, Opposition: Abe Doesn't Need Bill to Deal with Coronavirus, Asahi Shimbun, 5 March, 2020, available at: http://www.asahi.com/ajw/articles/photo/28558546, accessed on 1 March, 2021.

${ }^{63}$ Reiji Yoshida, and Satoshi Sugiyama, Abe Reaches Across isle for COVID-19 Emergency Law as Japan Cases Top 1,000, The Japan Times, 4 March, 2020, available at: https://www.japantimes.co.jp/news/2020/03/04/national/politicsdiplomacy/abe-opposition-coronavirus-emergency-law/, accessed on 1 March, 2021.

${ }^{64}$ Ibid.

${ }^{65}$ Shimizu Kazuki and Negita Masashi, "Lessons Learned from Japan's Response to the First Wave of COVID-19: A Content Analysis," Ibid., p. 7. 
combat the virus's spread. On March $30^{\text {th }}, 2020$, Koike requested residents to refrain from nonessential outings for the next two weeks due to a continued increase in Tokyo infections. ${ }^{66}$ On April $1^{\text {st }}, 2020$, the Ministry of Health, Labour and Welfare reconvened the Novel Coronavirus Expert Meeting to assess the current COVID-19 situation in Japan. On April $2^{\text {nd }}, 2020$, the Ministry also issued a notice that urged non-critical covid patients to move out of hospitals and stay at home or facilities designated by local governments. ${ }^{67}$ Prefectural governors across the country began arranging accommodation for such patients through hotel operators and dormitories and issued official requests to the Japan SelfDefense Force for transportation services. On April 3 ${ }^{\text {rd }}$, 2020, Professor Nishiura Hiroshi of the Ministry of Health's Cluster Response Team presented his COVID-19 epidemiological model's initial findings to the public. ${ }^{68} \mathrm{He}$ concluded ${ }^{69}$ that the government could prevent an explosive spread of the virus in Japan if it adopted strict restrictions on outings that reduced social interactions by 80 percent, while such a spread would occur if the government adopted no measures or reduced social interactions by only 20 percent. Nishiura added that Tokyo was about ten days to two weeks away from a largescale outbreak. This pushed Abe to proclaim a one-month state of emergency between $8^{\text {th }}$ April to $6^{\text {th }}$ May 2020 for Tokyo and the prefectures of Kanagawa, Saitama, Chiba, Osaka, Hyogo and Fukuoka. ${ }^{70}$ He stated that the number of patients would peak in two weeks if the number of person-to-person contacts was reduced by 70 to 80 percent, and urged the public to stay at home to achieve this goal. ${ }^{71}$

On April $10^{\text {th }}, 2020$, the government announced closure requests for six categories of businesses in Tokyo. ${ }^{72}$ They include amusement facilities, universities and cram schools, sports and recreation facilities, theatres, event and exhibition venues, and commercial facilities. The restaurants were also asked to limit their opening hours to between $5 \mathrm{am}$ and $8 \mathrm{pm}$ and to stop serving alcohol at $7 \mathrm{pm}$. The request took effect on April 12 $12^{\text {th }}, 2020$ and the government promised subsidies for businesses that cooperated with it. ${ }^{73}$ On April 11 ${ }^{\text {th }}$, 2020, Professor Nishiura presented the remaining findings of his epidemiological models. He was determined that reducing social interactions by 80 percent would decrease the infection rate to a manageable level in 15 days, by 70 percent in 34 days, by 65 percent in 70 days, and by 50 percent in 3 months. Any rate below 60 percent would increase the number of cases. ${ }^{74}$ By April $16^{\text {th }}, 2020$, Abe expanded the state of emergency declaration to include every prefecture within the country. Later on May $4^{\text {th }}, 2020$, Abe said that his cabinet would extend the state of emergency declaration until the end of May $2020 .^{75}$ Then on May $14^{\text {th }} 2020$, Abe declared that the government decided to relieve the state of emergency declaration, excluding eight prefectures like Tokyo, Kyoto Prefecture. Some media expressed doubts about why only some of the easing

\footnotetext{
${ }^{66}$ Rocky Swift, Experts Warn Japanese Growing Complacent of Coronavirus Risk, Reuters, 24 March, 2020, available at: https://www.reuters.com/article/us-health-coronavirus-japan-experts-idUSKBN21B130, accessed on 1 March, 2021.

${ }^{67}$ Ibid.

68 Julian Ryall, Coronavirus: Japan Warns Deaths Could Hit 420,000, amid Rising Anger at Government Response", The South China Morning Press, 15 April, 2020, available at: https://www.scmp.com/week-asia/healthenvironment/article/3080069/japan-warns-coronavirus-deaths-could-hit-400000-amid, accessed on 1 March, 2021.

${ }^{69}$ Ibid.

${ }^{70}$ Satoshi Sugiyama, Japan State of Emergency to Cover Tokyo, Osaka and Five Other Prefectures, The Japan Times, 6 April, 2020, available at: https://www.japantimes.co.jp/news/2020/03/04/national/politics-diplomacy/abe-oppositioncoronavirus-emergency-law/, accessed on 1 March, 2021.

${ }^{71}$ Ibid.

${ }^{72}$ Hisashi Tsutsui, and Yosuke Suzuki, Japan's Megacities Shut Down in Crucial Weekend to Fight Virus, Nikkei Asia, 28 March, 2020, available at: https://asia.nikkei.com/Spotlight/Coronavirus/Japan-s-megacities-shut-down-in-crucialweekend-to-fight-virus, accessed on 1 March, 2021.

${ }^{72}$ Ibid.

${ }^{73}$ Ibid.

${ }^{74}$ Ben Dooley, and Hikari Hida, Deaths Fell in Japan Last Year. How?, The New York Times, 24 February, 2021, available at: https://www.nytimes.com/2021/02/24/world/asia/japan-deaths.html?searchResultPosition=1, accessed on 1 March, 2021.

75 Nikkei Staff Writers, Japan Extends Emergency Nationwide ahead of Golden Week, Nikkei Asia, 16 April, 2020, available at: https://asia.nikkei.com/Politics/Japan-extends-emergency-nationwide-ahead-of-Golden-Week, accessed on 1 March, 2021.
} 
standards were released under the name of comprehensive judgment. ${ }^{76}$ On May $21^{\text {st }}, 2020$, the state of emergency was suspended in three prefectures in Kinki after they had cleared the threshold of having new infections below 0.5 per 100,000 people in the past week, resulting in a total of 42 out of the 47 prefectures to be out of the state of emergency. Meanwhile five prefectures, such as Saitama, Kanagawa, Hokkaido, were waiting for a lifting decision on $25^{\text {th }}$ May 2020. By the time Prime Minister Suga took over as the new prime minister in September 2020, escalating public criticisms reached an unprecedented level of disappointments with the incumbent Liberal Democratic Party (LDP) government.

\section{PUBLIC CRITICISMS}

Nonetheless, the Japanese government under the former Shinzo Abe's and current Yoshihide Suga's administrations suffered several setbacks due to lack of immediate and adequate response, which further translated into mixed public opinions on the government's ineffectiveness in dealing with the crisis. In the middle of February 2020, media outlets criticized the limited and restrictive outlets for testing as it would further spread the disease. ${ }^{77}$ In fact, several Japanese media outlets reported that people with fever or other symptoms could not be tested and had become "test refugees". ${ }^{78}$ Haematologist Masahiro Kami claimed that many suspected patients among elderly populations were denied testing. ${ }^{79}$ Some even question the discrepancy between the actual number of people tested and the claim in the prior weeks of February 2020 since the Ministry's systematic attempt to reduce dailyreported results of tested positive. ${ }^{80}$ By March 2020, the Japan Medical Association announced that it would start a nationwide investigation and plan to pressure the Abe administration to improve the condition. ${ }^{81}$ The strict constraints on testing for the virus by the health authorities drew widespread speculations from Japanese opposition leaders, civil society activists and renounced health experts that Abe wanted to "downplay the number of infection or patients because of the upcoming Olympics". 82 By middle year of the 2020, it was reported that only a few public health facilities were authorizes to test the virus, after which results could only be processed by five-government approved companies, resulted in delayed of the actual daily statistics announced by the Ministry. This has led some global health experts to question Japan's official case numbers. "You wonder, if they were testing nearly as

\footnotetext{
76 Dennis Normile, Japan Ends Its COVID-19 State of Emergency, Science Magazine, 26 May, 2020, available at: https://www.sciencemag.org/news/2020/05/japan-ends-its-covid-19-state-emergency, accessed on 1 March, 2021.

77 Brad Glosserman, COVID-19 Crisis Could Get Much Worse, The Japan Times, 25 February, 2020, available at: https://www.japantimes.co.jp/opinion/2020/02/25/commentary/japan-commentary/covid-19-crisis-get-much-worse/, accessed on 1 March, 2021.

${ }^{78}$ Koichi Nakano, Japan Can't Handle the Coronavirus. Can It Host the Olympics? The New York Times, 26 February, 2020, available at: https://www.nytimes.com/2020/02/26/opinion/coronavirus-japan-abe.html, accessed on 1 March, 2021.

${ }^{79}$ Ryusei Takahashi, Anxiety in Coronavirus in 2020 Spurs Unprecedented Societal Change in japan. Will It Last?, The Japan Times, 19 December, 2020, available at: https://www.japantimes.co.jp/news/2020/12/19/national/socialissues/2020-in-review-covid-19-wrap/, accessed on 1 March, 2021.

${ }^{80}$ Daniel P. Aldrich, and Toshiaki Yoshida, “How Japan Stumbled into a Pandemic Miracle?", Current History, Vol. 119, No. 818, 2020, p. 220.

${ }^{81}$ Jeff Kingston, COVID-19 Is a Test for World Leaders. So Far, Japan's Abe Is Failing, The Diplomat, 23 April, 2020, available at: https://thediplomat.com/2020/04/covid-19-is-a-test-for-world-leaders-so-far-japans-abe-is-failing/, accessed on 1 March, 2021.

${ }^{82}$ Victor Mathew, and Motoko Rich, Despite Virus Surge, I.O.C. Pledges Summer Olympics in Tokyo Will Happen, The New York Times, 21 January, 2021, available at: https://www.nytimes.com/2021/01/21/sports/olympics/bach-olympicstokyo-covid.html, accessed on 1 March, 2021.
} 
much as South Korea is testing, what would be the actual number be?" ${ }^{83}$ Eventual fact-checking ${ }^{84}$ in several media later proved that the government had reduced the number of tests to curb the increase in the number of infected people for the Olympic was not accurate at all.

The Japan government opted to advise people to not go out and request shops and restaurants to suspend their business. The Japan government calls the public to avoid the "three Cs", which is crowded space, closed space with poor ventilation and close conversation with other people. Another effort made by the Japanese government is to do inspections, especially among the elderlies which is the most vulnerable group of COVID-19. However, most municipal governments did not follow the order to increase the inspection as there is now lack of fund to do so since their budget has been spent in the second wave, although the central government had promised to bear half of the inspection cost. ${ }^{85}$ The method of the Japan government in handling COVID-19 might be surprising due to the fact that Japan is more vulnerable to this infectious pandemic compared to other countries. This is due to three main reasons: the crowded metropolitan of the greater Tokyo area and Osaka, the ageing population, and the proximity with China. With its population of more than 30 million people, the greater Tokyo area is one of the world's highest density metropolitan area. With its high density, it is easier for the droplets transmitted pandemic. This is even more obvious in public transport, such as trains that are very crowded and social distancing is almost impossible to apply. Besides, the Japanese ageing society also made Japan more vulnerable to Covid- $19 .{ }^{86}$

In addition, Japan's "ambiguous and passive quarantine efforts" resulted in criticisms from South Korea. ${ }^{87}$ In response to this criticism, Abe decided to design new quarantine measures for entrants from China, South Korea and other countries that show high numbers of infected cases when travelling to Japan. Yet, the decision was proven to be late as Abe was trying to be careful with China while South Korea turned it into a bilateral tension. ${ }^{88}$ Perhaps, the biggest challenge leading to erosions of public confidence upon Abe's leadership when responding to the crisis is his initial refusal to cancel the original 2020 Summer Olympics that was meant to be scheduled in July $2020 .{ }^{89}$ The deferment was only realized after Abe agreed to negotiate a new schedule of July 2020 with the International Olympic Committee. By January 2021, Prime Minister Suga attempted to dismiss more calls of another year of postponement due to the budget deficit and US\$ 12 billion allocation spent so far in the preparation of Tokyo as the host. ${ }^{90}$ The plan for postponed of the Tokyo Olympic games grew more uncertain by February 2021. For weeks, the Japanese government has insisted that the Games go

\footnotetext{
${ }^{83}$ Philip Bump, "The Administration Keeps Bragging that U.S. Testing Now Is Better than South Korea's Was Months Ago, Washington Post, 12 May, 2020, available at: https://www.washingtonpost.com/politics/2020/05/11/administrationkeeps-bragging-that-us-testing-now-is-better-than-south-koreas-was-months-ago/, accessed on 1 March, 2021.

84 Azby Brown, Uncertainties about Japan's COVID-19 Data, Safecast, 28 April, 2020, available at: https://safecast.org/2020/04/uncertainties-about-japans-covid-19-data/, accessed on 1 March, 2021.

${ }^{85}$ N. Sugaya, T. Yamamoto, N. Suzui, et al. "A Real-Time Survey of the Psychological Impact of Mild Lockdown for COVID-19 in the Japanese Population”, Scientific Data, Vol. 7, No. 1, 2020, p. 372.

${ }^{86}$ Xiaochen Su, Lack of Transparency Complicates Japan's Handling of COIVD-19, The Diplomat, 6 February, 2021, available at: https://thediplomat.com/2021/02/lack-of-transparency-complicates-japans-handling-of-covid-19/, accessed on 1 March, 2021.

87 Yexin Mao, "Combating COVID-19 Through Collaborative Governance: Lessons from East Asia”, Chinese Public Administration Review, Vol. 11, No. 2, 2020, p. 135.

${ }^{88}$ William Sposato, Japan and Korea Won't Let A Pandemic Stop Them Fighting, Foreign Policy, 12 March, 2020, available at: https://foreignpolicy.com/2020/03/12/japan-and-korea-wont-let-a-pandemic-stop-them-fighting/, accessed on 1 March, 2021.

${ }^{89}$ Van Tuan Hoang, Jaffar A. Al Tawfiq, and Philippe Gautret, "The Tokyo Olympic Games and the Risk of COVID-19", Current Tropical Medicine Report, Vol. 7, 2020, p. 128.

${ }^{90}$ Mathew Futterman, Hopes for Tokyo's Summer Olympics Darken, The New York Times, 15 January, 2021, available at: https://www.nytimes.com/2021/01/15/sports/olympics/tokyo-olympics.html?searchResultPosition=8, accessed on 1 March, 2021.
} 
forward and that further delay is not possible. ${ }^{91}$ While there is no further assurance on how the Games could be held safely, Japan issued a new health directive in which athletes and attendees will not be required to be vaccinated or quarantined upon their arrival in Japan. ${ }^{92}$ As a result, a public opinion against the Games, and as conducted by NHK showed that 77 percent of the Japanese favoured in cancelling or postponing the Games. ${ }^{93}$

Arguably, the measurement taken by both administrations of Abe and Suga might be working in the early days of this pandemic, but it has failed to contain the virus and has created the second and, more recent third wave infection, which resulted in another emergency proclamation for greater Tokyo in January of 2021. Thus, the "advice" of the Japanese government, requesting its citizen to stay at home and reducing operating hours of restaurants and shops, or the request of avoiding the "three Cs", does not bring a significant impact in managing this pandemic. The Japanese tradition and culture might play a more influential role in containing the virus in the early stage. ${ }^{94}$ Since COVID-19 is transmitted through droplets mostly from our mouth when we speak or sneeze, it is essential to wear a mask or keep a safety distance from the others to avoid the contact of flying droplets (airborne disease). Therefore, the Japanese culture of greetings that do not favour physical contact, their preference of bowing instead of handshakes, and their habits of wearing face mask whenever they feel uncomfortable during winter are more convincing explanations for why the COVID-19 did not spread widely during the early to mid-2020. ${ }^{95}$ In contrast, the westerners have the habit of shaking their hand when greeting others, but in Japan, shaking each other hands are not common. Instead, they bow to each other to show respect. Given these cultural differences between Japan and other countries, it certainly makes a huge difference in containing the virus. Therefore, the probability for the younger generations to be infected by the COVID-19 virus is lower. They are also more comfortable adapting to the new norm of social (psychical) distancing with others during the pandemic era because what they need to act does not have a greater difference with what they always have been cultivated to practice in the past. Besides, the Japanese also have the habit of going out wearing a mask, especially during the winter season or when they catch a cold. It is a usual practice for the Japanese to wear a mask if they were sick.

Nonetheless, while Japanese social practices facilitate the government's countermeasures against COVID-19, the hike of daily infected cases in the second wave and third wave was most likely caused by their government's campaign, "Go To". 96 "Go To" policy covers two different aspects, namely, "Go To" travel and "Go To" eat. This government-initiated campaign gives the Japanese certain discounts on local tourism activities when they travel domestically. This campaign started in July 2020 with the aim to stimulate the economy. In fact, the increment of infected cases starting from July is believed to be caused by this campaign where many elderlies travelled to cities such as Sapporo, Tokyo, or Osaka and caused infected cases to arise in these cities, making them become among the

\footnotetext{
${ }^{91}$ Rachel Bachman, A Tokyo Olympics Mystery: What Happens With 80,000 Volunteers During a Pandemic?, The Wall Street Journal, 4 March, 2021, available at: https://www.wsj.com/articles/tokyo-olympics-volunteers-pandemic11614821947 , accessed on 1 March, 2021.

92 Editors, Olympics Organisers Unveil COVID Rules. ALJAZEERA, 3 February, 2021, available at: https://www.aljazeera.com/news/2021/2/3/olympics-organisers-unveil-covid-rulebook-for-tokyo-games, accessed on 1 March, 2021.

${ }^{93}$ Susumu Cato, Takashi Iida, Asei Ito, et al. "The Bright and Dark Sides of Social Media Usage during the COVID-19 Pandemic: Survey Evidence from Japan”, Reduction, Vol. 54, February, 2021, p. 2.

${ }^{94}$ Massimo Leone, “The Semiotics of the Anti-COVID-19 Mask: Evidence from Japan”, Social Semiotics, 2021, available at: https://doi-org.ezproxy.um.edu.my/10.1080/10350330.2020.1868943, accessed on 1 March, 2021.

${ }_{95}$ Brian W. Haas, Fumiko Hoeft, and Kazufumi Omura, "The Role of Culture on the Link Between Worldviews on Nature and psychological Health during the COVID-19 Pandemic", Personality and Individual Differences, Vol. 170, February, 2021, available at: DOI: 10.1016/j.paid.2020.110336, accessed on 1 March, 2021.

${ }^{96}$ Brian W. Haas, Fumiko Hoeft, and Kazufumi Omura, "The Role of Culture on the Link Between Worldviews on Nature and psychological Health during the COVID-19 Pandemic", Personality and Individual Differences, Vol. 170, February, 2021, available at: DOI: 10.1016/j.paid.2020.110336, accessed on 1 March, 2021.
} 
top COVID-19 spots in Japan. ${ }^{97}$ It is also important to take note that albeit the overall policy used by the Japanese government to curb the spreading of the pandemic may seem ineffective, Japan yet shows low mortality rate compared with other countries. One crucial point is that the elderly represent 25 percent of the overall Japanese population. While these age groups are regarded as high risks in other covid-related countries, Japan's mortality rate is relatively low. ${ }^{98}$ This is mostly due to the readiness of the Japan's medical facilities in responding to the public outcries after the initial delayed in prioritizing the needs of the most vulnerable population of the country.

\section{FINDINGS: JAPANESE POLITICAL LEADERSHIP IN TIMES OF PANDEMIC CRISIS}

The COVID-19 pandemic was one of the enduring public health crises, overstretching Japan's national and global capabilities to identify and respond. For any pandemic crisis of transnational scale, it is critical for political leaders to take responsibility early, to organize and respond to the key dimensions of analyzing and response. Political leaders must also ensure that all assigned delivery stakeholders are empowered to keep the discussion focused on decision-making and ensure effective communications. Our analysis of Japan under Abe and Suga have shown a mixed evident of success and setbacks in performing leadership capabilities in the precarious turbulence of COVID-19. While both Abe and Suga were expressing initial commitments of demonstrating political leadership, COVID-19 response was highly hierarchical and top-down in its delivery system, resulting in steadily slow and delayed emergency response in convincing the Japanese public upon a priority of containing the infection lines. ${ }^{99}$ The COVID-19 response of Abe was complicated, with a lot of delay emergency actions that revolved around the decision to prevent the Olympic games' postponement. This is similar to Suga's weak leadership in convincing the public of the delayed in the vaccination programme. Both Abe and Suga proved to be unable in fulfilling the second leadership principle in effectively leading the national task force of COVID-19. Among the chief of Abe's criticisms is his refusal to instantly listen to the top national health experts in moving towards the actual proclamation of emergency when the first wave erupted. While Suga attempts to engage health experts in his major decisions, it was rather a case of too little too late. ${ }^{100}$ While some praised Japan's initial success in reducing the number of infected persons by July of 2020, the spike of new cases was recoded when Abe prematurely relaxed the regulations and eventually pushed Suga for another declaration of emergency for Tokyo in January 2021. ${ }^{101}$ However, Japan's model is regarded as relatively a success compared to other developed countries, especially in demonstrating the delivery of the third principle of leadership. This is well exhibited in both Abe's and Suga's consistent commitments in taking and leading the ownership of the pandemic response mechanisms. Still, both Abe and Suga are incompetent in demonstrating the fourth leadership traits, which utilizes Japan's world class healthcare infrastructures and renounced pandemic experts when engaging with the high-risk and most-vulnerable segments of the society. In

\footnotetext{
${ }^{97}$ Myo Nyein Aung, Motoyuki Yuasa, Yuka Koyanagi, and et al. "Sustainable Health Promotion for the Senior during COVID-19 Outbreak: A Lesson from Tokyo", The Journal of Infection in Developing Countries, Vol. 14, No. 4, 2020, p. 329.

${ }^{98}$ Sachiko Kodera, Essam A Rashed, and Akimasa Hirata. "Correlation between COVID-19 Morbidity and Mortality Rates in Japan and Local Population Density, Temperature, and Absolute Humidity", Environmental Research and Public Health, Vol. 17, 2020, p. 10.

99 A. V. Belov, "Economic Policy of Japan in the Time of Pandemic", World Economy and International Relations, Vol. 65, No. 1, 2021, p. 39.

${ }^{100}$ Dainel Leussink, and Mari Saito, Suga Faces Mounting Pressures Over Slow Pandemic Response, The Japan Times, 25 January, 2021, available at: https://www.japantimes.co.jp/news/2021/01/25/national/japan-suga-coronavirus-response/, accessed on 1 March, 2021.

${ }^{101}$ Satoshi Sugiyama, Suga Aims to Turn Page with Coronavirus Emergency Extension, The Japan Times, 2 February, 2021, available at: https://www.japantimes.co.jp/news/2021/02/02/national/suga-emergency-coronavirus-japan/,_accessed on 1 March, 2021.
} 
evaluating Abe and Suga's abilities to perform the fifth leadership principle, especially in maintaining a strong international network, it was evident that the pandemic sparked escalating public outcries against Abe's initial reluctances and delayed responses to contain sources of infections from Wuhan China. Meanwhile, Suga has shown a better leadership record of prioritizing a precise international relations direction with the $\mathrm{WHO}$ and countries involved in facilitating companies to export the vaccine supplies ${ }^{102}$. Most importantly, variations of leadership traits between Abe and Suga confirmed the importance of the sixth key principle of political leadership in a time of crisis. Calamities, and setbacks truly evaluate both leadership abilities fluctuated from the pandemic, especially in managing the overpromised and undelivered expectations of the Japanese public.

Towards the end of Abe administration and the dawn of newly appointed Suga as the prime minister, the Japanese government is optimistic in moving towards the recovery mode of postpandemic, especially in meeting a new deadline of deferred Tokyo Olympic to July 2021 and the arrival of the vaccine supply by February 2021. By September 2020, Japan falls into recession. ${ }^{103}$ Existing economic and austerity packages announced by the government have not shown a clear indication that the temporary success of fighting COVID-19 contributes to a recovered direction of the economic upturn. ${ }^{104}$ When Suga replaced Abe, he enjoyed the highest approval rating in September 2020. ${ }^{105}$ By January 2021, and at the time of this writing, it is evident that Suga leadership is predicted to be heavily assessed with his direction in dealing with the pandemic, making him as another usual suspect of short-term prime minister. Commentators have highlighted a very unlucky scenario for Suga compared to former Abe as the country grasped with the health crisis. ${ }^{106}$ While Abe was heavily criticized, he remained politically popular among the conservative voters due to his strong political rhetoric against China and South Korea. Apart from crisis of confidence from within and outside of the ruling establishment, Suga's humble political beginning as a son of a farmer and without a direct patronage connection with one of the factions within the LDP translates into his lack of popular based to lead LDP for the upcoming election. ${ }^{107}$ As the ruling LDP is heading for the lower house election, the public opinion surveyed by Mainichi newspaper has estimated that 57 percent of respondents cited Suga's ineffectiveness as a leader. ${ }^{108}$ The Japanese public is very sceptical with Suga at the outset of his administration since he was accused of putting the economy over the health sector. Arguably, Suga has been unfortunate in the timing of his take-over of the government as it had coincided with the incumbent LDP's inefficiency in dealing with the pandemic and several political scandals that had occurred before he assumed to the prime minister post. Katsuyuki Kawai, a former justice minister and a protégé of Suga has been charged with buying votes to assist his wife's campaign during the election

102 Tetsushi Kajimoto, Japan's Suga Hopes to Suceed PM Abe, Race Heats Up, Reuters, 30 August, 2020, available at: https://www.reuters.com/article/us-japan-politics-idUSKBN25Q03M, accessed on 1 March, 2021.

${ }^{103}$ Ben Dooley, and Makiko Inoue, Japan's Growth Rebounds, but Virus-Related Weakness Looms, The New York Times, 14 February, 2021, available at: https://www.nytimes.com/2021/02/14/business/japan-gdp-economycoronavirus.html?searchResultPosition=3, accessed on 1 March, 2021.

${ }^{104}$ Suetgiin Soon, Chelsea C. Chou, and Shih-Jiunn Shi, "Withstanding the Plague: Institutional Resilence of the East Asian Welfare State", Social Policy \& Administration, February, 2021, available at: DOI: 10.1111/spol.12713, accessed on 1 March, 2021.

105 Takuya Mizorogi, Japan's Suga Slips to 42\% Approval Rating in New Nikkei Poll, Nikkei Asia, 28 December, 2020, available at: https://asia.nikkei.com/Politics/Japan-s-Suga-slips-to-42-approval-rating-in-new-Nikkei-poll, accessed on 1 March, 2021.

${ }^{106}$ Editors, Japan's Coronavirus Surge Makes PM Suga Look More Like Short-Term Leader, The Straits Times, 17 January, 2021, available at: https://www.straitstimes.com/asia/east-asia/japans-coronavirus-surge-makes-pm-suga-look-more-likeshort-term-premier, accessed on 1 March, 2021.

${ }^{107}$ Editors, Meet Yoshihide Suga, a Farmer Son Who Is Set to Become Japan's Next Prime Minister, The Economic Times, 15 September, 2020, available at: https://economictimes.indiatimes.com/news/international/world-news/meet-yoshihidesuga-a-farmers-son-who-is-set-to-become-japans-next-prime-minister/shinzo-abes-successor/slideshow/78122652.cms, accessed on 1 March, 2021.

108 Editors, “Approval Rating for Japan PM's Suga Cabinet Dives amid Discontent Over COVID-19 Response”, The Mainichi, 14 December, 2020, available at: , https://mainichi.jp/english/articles/20201214/p2a/00m/0na/003000c, accessed on 1 March, 2021. 
from Hiroshima Prefecture. ${ }^{109}$ Nonetheless, Suga leadership has been imploding in the public polls as voters are squarely pinning the blame for the latest infection wave that Japan is currently experiencing. Lessons from the Japanese leadership of Abe and Suga in time of crisis are very instructive in highlighting that communication with the public is needed to keep people informed on accurate facts and provide appropriate reassurance and hope, particularly about steps they can take to get through the crisis. Our findings have illuminated the invisibility of political leadership in managing the pandemic as a political crisis. In doing so, we highlight the potentials and pitfalls of leadership in getting through the pandemic periods and helping the country move to a non-crisis condition.

\section{CONCLUSION: MALAYSIAN DEMOCRACY AND POLITICS OF CORONAVIRUS}

In learning from Japanese leadership under Abe and Suga, we need to explore the unfolding relations between political leadership, democratic setbacks, and politics of COVID-19 in our country, Malaysia. Interestingly, and at the dawn of the pandemic in February 2020, Malaysia witnessed a shift of government, albeit the undemocratic change is ferociously debated. When the former Pakatan Harapan (PH) government collapsed, and Perikatan Nasional (PN) took over, alarming COVID-19 cases were on the rise and further exacerbated by national leaders' failure to focus on the actual priority of the public health. ${ }^{110}$ It was only by the middle of March 2020, a total lockdown measure, termed as Movement Control Order (MCO) was installed for the new government under Prime Minister Muhyiddin Yasin to focus on the health crisis from the pandemic. ${ }^{111}$ Therefore, we cannot say that the Japanese model is viable, yet we can still learn something from it. As effective as one may perceive, this does not mean that it would work well for other countries to implement in their own system given Malaysia's capability, especially the demographic, healthcare system, and sociocultural resonance. Malaysia's initial success in reducing daily infected cases and flattening the infection curves was praised by many Malaysians, especially after prolonged episodes of political fatigues and tussles among former PH leaders. ${ }^{112}$ However, towards the end of 2020 and early 2021, public sceptics upon the government's capability to manage the pandemic, inconsistent quarantine directives and ambiguous standard operating procedures (SOPs) in managing economic activities and continued violations of pandemic SOPs by leaders have led to the belief of COVID-19 as a political pretext for the newly PN government to remain in power. ${ }^{113}$

Thus, lessons from Japan for Malaysia are apparent here: to interpret the ongoing pandemic purely in terms of public health issues risks overlooking potentially more significant socio-political consequences. This is because the challenges posed by the COVID-19 pandemic have themselves become overlaid or layered-upon a pre-existing set of concerns and tensions regarding unfinished power tussles and political transitions, overpromised and undelivered 2018's election manifesto, elite

\footnotetext{
${ }^{109}$ Editors, Coronavirus, Political Scandals Hit Japanese Leader Suga's Popularity, Made for Minds, 25 December, 2020 , available at: https://www.dw.com/en/japan-pm-yoshihide-suga-declining-popularity/a-5611080, accessed on 1 March, 2021.

${ }^{110}$ Editors, Coronavirus, Political Scandals Hit Japanese Leader Suga's Popularity, Made for Minds, 25 December, 2020, available at: https://www.dw.com/en/japan-pm-yoshihide-suga-declining-popularity/a-5611080, accessed on 1 March, 2021.

${ }^{111}$ Chris Fook Sheng Ng, Xerxes T. Seposo, Meng Ling Moi, et al. "Characteristics of the COVID-19 Epidemic and Control Measures to Curb Transmission in Malaysia," International Journal of Infectious Diseases, Vol. 101, December, 2020, p. 410.

112 Dhesegaan Bala Krishnan, Survey Shows Malaysians Blame Politics, Not Pandemic, The Strait Times, 16 October, 2020, available at: https://www.nst.com.my/news/nation/2020/10/632868/survey-shows-malaysians-blame-politics-notpandemic-economic-woes, accessed on 1 March, 2021.

113 Anuradha Raghu, How the Pandemic Is Keeping Malaysia’s Politics Messy, Bloomberg, 12 January, 2021, available at: https://www.bloomberg.com/news/articles/2021-01-12/how-the-pandemic-is-keeping-malaysia-s-politics-messyquicktake, accessed on 1 March, 2021.
} 
brinkmanship games and disfranchised Malaysian voters within the existing politicization of communal and religious conundrums. In the long run, dealing with the health pandemic as a political pretext will be providing a menu of political manipulation in endangering and downgrading the performance, efficiency and capacity of reforms and leadership accountability in the authoritarian democracy of Malaysia to function. ${ }^{114}$ Therefore, it is very pertinent to understand and warn against what might be termed a rather odd form of cross-contamination whereby cynicism, negativity, and frustrations of the public upon politicians, political processes and political institutions that existed before the pandemic outbreak is allowed to direct, define and automatically devalue how democratic structures are subsequently judged in terms how leaders and state apparatus responded to the future challenge. Nevertheless, stories from both Japan and Malaysia have shown that the idea of keeping democracy during a pandemic has already proved problematic where politicians hijacked the pandemic to claim emergency and extrajudicial powers to strengthen their position. ${ }^{115}$ Simultaneously, the victorious claims of subduing the COVID-19 have raised potentially far-reaching questions about whether authoritarian regimes handle pandemics more effectively than democratic ones.

\footnotetext{
${ }^{114}$ Kevin Fernandez, "Three Waves of Hate Speech Spreading Faster than the Pandemic in Malaysia: An Analyses of Outgroup Populist Narratives and Hate Speech during the COVID-19," GEOGRAFIA: Malaysian Journal of Society and Space, Vol. 16, No. 4, 2020, p. 287.

${ }^{115}$ Richard Carver, "Human Rights Practice in the Age of Pandemic," Journal of Human Rights Practice, Vol. 12, No. 2, 2020 , p. 248.
} 


\section{REFERENCES}

A. V. Belov, "Economic Policy of Japan in the Time of Pandemic", World Economy and International Relations, Vol. 65, No. 1, 2020, pp. 33-41.

Ai Tashiro, Rajib Shaw, "COVID-19 Pandemic Response in Japan: What is Behind Flattening of the Curve?”, Sustainability, Vol. 12, No.3, 2020, pp. 1-15.

Anuradha Raghu, How the Pandemic Is Keeping Malaysia's Politics Messy, Bloomberg, 12 January, 2021, available at: https://www.bloomberg.com/news/articles/2021-01-12/how-the-pandemic-iskeeping-malaysia-s-politics-messy-quicktake, accessed on accessed on 1 March, 2021.

Asahi Writers, Opposition: Abe Doesn't Need Bill to Deal with Coronavirus, Asahi Shimbun, 5 March, 2020, available at: http://www.asahi.com/ajw/articles/13188487, accessed on accessed on 1 March, 2021.

Atsuna Tokumoto, Hiroki Akaba, Hitoshi Oshitani, et al. "COVID-19 Health System Response Monitor: Japan", Asia Pacific Observatory on Health Systems and Policies, January 2021, available at: https://apps.who.int/iris/handle/10665/338399, accessed on accessed on 1 March, 2021.

Azby Brown, Uncertainties about Japan's COVID-19 Data, Safecast, 28 April, 2020, available at: https://safecast.org/2020/04/uncertainties-about-japans-covid-19-data/, accessed on accessed on 1 March, 2021.

BBC Writers, Coronavirus: Japan Doctors Warn of Health System 'Break Down' as Cases Surge, $B B C, 18$ April, 2020, available at: https://www.bbc.com/news/world-asia-52336388, accessed on accessed on 1 March, 2021.

Ben Dooley and Makiko Inoue, Testing Key to Beating Coronavirus, Right? Japan Has Other Ideas, The New York Times, 28 August, 2020, available at: https://www.nytimes.com/2020/05/29/world/asia/japan-coronavirus.html, accessed on accessed on 1 March, 2021.

Ben Dooley, Hikari Hida, Deaths Fell in Japan Last Year. How?, The New York Times, 24 February, 2021, available at: https://www.nytimes.com/2021/02/24/world/asia/japan-deaths.html, accessed on accessed on 1 March, 2021.

Ben Dooley, Makiko Inoue, Japan's Growth Rebounds, but Virus-Related Weakness Looms, The New York Times, 14 February, 2021, available at: https://www.nytimes.com/2021/02/14/business/japangdp-economy-coronavirus.html, accessed on accessed on 1 March, 2021.

Ben Dooley, Shinzo Abe, Japan's Political Houdini, Can't Escape Coronavirus Backlash, The New York Times, 10 March, 2020, available at: https://www.nytimes.com/2020/03/05/world/asia/japanabe-coronavirus.html, accessed on accessed on 1 March, 2021.

Brad Glosserman, COVID-19 Crisis Could Get Much Worse, The Japan Times, 25 February, 2020, available at: https://www.japantimes.co.jp/opinion/2020/02/25/commentary/japancommentary/covid-19-crisis-get-much-worse/, accessed on 1 March, 2021. 
Brian W. Haas, Fumiko Hoeft, and Kazufumi Omura, "The Role of Culture on the Link Between Worldviews on Nature and psychological Health during the COVID-19 Pandemic", Personality and Individual Differences, Vol. 170, 2021, available at: 10.1016/j.paid.2020.110336, accessed on 1 March, 2021.

Carla Norrlof, "Is COVID-19 the end of US Hegemony? Public Bads, Leadership Failures and Monetary Hegemony", International Affairs, Vol. 96, No. 5, 2020, pp. 1281-1301.

Chris Fook Sheng Ng, Xerxes T. Seposo, Meng Ling Moi, et al. "Characteristics of the COVID-19 Epidemic and Control Measures to Curb Transmission in Malaysia", International Journal of Infectious Diseases, Vol. 101, December, 2020, pp. 409-411.

Dainel Leussink, Mari Saito, Suga Faces Mounting Pressures Over Slow Pandemic Response, The Japan Times, 25 January, 2021, available at: https://www.japantimes.co.jp/news/2021/01/25/national/japan-suga-coronavirus-response/, accessed on 1 March, 2021.

Daisuke Akimoto, COVID-19 and Japan's Global Health Strategy: Developing Vaccines in a Human Security Crisis, Institute for Security \& Development Policy, May 6, 2020, available at: https://isdp.eu/covid-19-japans-global-health-strategy/, accessed on 1 March, 2021.

Daniel P. Aldrich, Toshiaki Yoshida, "How Japan Stumbled into a Pandemic Miracle?", Current History, Vol. 119, No. 818, 2020, pp. 217-221.

Dennis Normile, Japan Ends Its COVID-19 State of Emergency, Science Magazine, May 26, 2020, available at: https://www.sciencemag.org/news/2020/05/japan-ends-its-covid-19-state-emergency, accessed on 1 March, 2021.

Dhesegaan Bala Krishnan, Survey Shows Malaysians Blame Politics, Not Pandemic, The Strait Times, 16 October, 2020, available at: https:/www.nst.com.my/news/nation/2020/10/632868/survey-showsmalaysians-blame-politics-not-pandemic-economic-woes, accessed on 1 March, 2021.

Editor, Japan Declares State of Emergency Over Coronavirus, The Guardian, 7 April, 2020, available at: https://www.theguardian.com/world/2020/apr/07/japan-shinzo-abe-declares-state-of-emergencyover-coronavirus, accessed on 1 March, 2021.

Editor. "Unprecedented Times? Social Work and Society post-COVID-19”, British Journal of Social Work, Vol. 50. 2020, pp. 1297-1303.

Editors, Approval Rating for Japan PM's Suga Cabinet Dives amid Discontent Over COVID-19 Response, The Mainichi, 14 December, 2020, available at: https://mainichi.jp/english/articles/20201214/p2a/00m/0na/003000c, accessed on 1 March, 2021.

Editors, Coronavirus, Political Scandals Hit Japanese Leader Suga's Popularity, Made for Minds, 25 December, 2020, available at: https://www.dw.com/en/japan-pm-yoshihide-suga-decliningpopularity/a-56110806, accessed on 1 March, 2021.

Editors, Japan's Coronavirus Surge Makes PM Suga Look More Like Short-Term Leader, The Straits Times, 17 January, 2021, available at: https://www.straitstimes.com/asia/east-asia/japans-coronavirussurge-makes-pm-suga-look-more-like-short-term-premier, accessed on 1 March, 2021. 
Editors, Meet Yoshihide Suga, a Farmer Son Who Is Set to Become Japan's Next Prime Minister, The Economic Times, 15 September, 2020, available at: https://economictimes.indiatimes.com/news/international/world-news/meet-yoshihide-suga-afarmers-son-who-is-set-to-become-japans-next-prime-minister/shinzo-abessuccessor/slideshow/78122652.cms, accessed on 1 March, 2021.

Editors, Olympics Organisers Unveil COVID Rules, ALJAZEERA, 3 February, 2021, available at: https://www.aljazeera.com/news/2021/2/3/olympics-organisers-unveil-covid-rulebook-for-tokyogames, accessed on 1 March, 2021.

Eric A. Fieldman, Did Japan's Lenient Lockdown Conquer the Coronavirus?, The Regulatory Review, 10 June, 2020, available at: https://www.theregreview.org/2020/06/10/feldman-japan-lenientlockdown-conquer-coronavirus/, accessed on 1 March, 2021.

Francois Gerard, Clement Imbert and Kate Orkin, "Social Protection Response to the COVID-19 Crisis: Options for Developing Countries", Oxford Review of Economic Policy, Vol. 31, No. 1, 2020, pp. S281-S296.

G. Caplan, Principles of Preventive Psychiatry. New York: Basic Books, 1964.

Haiqian Chen, Leiyu Shi, Yuyao Zhang, et al. "A Cross-Country Core Strategy Comparison in China, Japan, Singapore and South Korea during the Early COVID-19 Pandemic", Globalization and Health, Vol. $17, \quad$ No. 1, 2021, available at: https://globalizationandhealth.biomedcentral.com/articles/10.1186/s12992-021-00672-w, accessed on 1 March, 2021.

Hasan, Saulam, Kanda, et al. "Trends in COVID-19 Outbreak in Tokyo and Osaka from January 25 to May 6 2020,” Japanese Journal of Infectious Disease, Vol. 74, No. 1, 2021, pp.73-75.

Hisashi Tsutsui, and Yosuke Suzuki, Japan's Megacities Shut Down in Crucial Weekend to Fight Virus, Nikkei Asia, 28 March, 2020, available at: https://asia.nikkei.com/Spotlight/Coronavirus/Inpictures-First-weekend-of-Tokyo-shutdown-to-stem-coronavirus, accessed on 1 March, 2021.

Isabel Ryenolds, Japan's Abe Follows Trump in Fast Drug Approvals After Criticism, Bloomberg, 12 May, 2020, available at: https://www.bloomberg.com/news/articles/2020-05-11/japan-s-abe-followstrump-in-fast-drug-approvals-after-criticism, accessed on 1 March, 2021.

Isabella Steger, Japan Finally decided to Hold a Virtual Cabinet Meeting as a Coronavirus Precaution, Quartz, 31 May, 2020, available at: https://qz.com/1849256/japan-cabinet-finally-holds-first-virtualmeeting-during-coronavirus/, accessed on 1 March, 2021.

Japan's Abe Orders Gov't to Draft Policy to Fight COVID-19, Xinhua News, 23 February, 2020, available at: http://www.xinhuanet.com/english/2020-02/23/c_138811067.htm, accessed on 1 March, 2021.

Jeff Kingston, COVID-19 Is a Test for World Leaders. So Far, Japan's Abe Is Failing, The Diplomat, 23 April, 2020, available at: https://thediplomat.com/2020/04/covid-19-is-a-test-for-world-leaders-sofar-japans-abe-is-failing/, accessed on 1 March, 2021. 
Jiji, Abe Reluctant to Head Calls for Coronavirus Law Revisions, The Japan Times, 3 August, 2020, available at: https://www.japantimes.co.jp/tag/shinzo-abe/page/15/, accessed on 1 March, 2021.

Julian Ryall, Coronavirus: Japan Warns Deaths Could Hit 420,000, amid Rising Anger at Government Response, The South China Morning Press, 15 April, 2020, available at: https://www.scmp.com/weekasia/health-environment/article/3080069/japan-warns-coronavirus-deaths-could-hit-400000-amid, accessed on 1 March, 2021.

Julian Ryall, Coronavirus: Japan's Employees are Working From Home, but Stress has Followed Them, The South China Morning Press, 13 April, 2020, available at: https://www.scmp.com/weekasia/health-environment/article/3079646/coronavirus-japans-employees-are-working-home-stress, accessed on 1 March, 2021.

Junichi Oshita, As Japan Lags in Coronavirus Tests, Companies too Triple Capacity, Nikkei Asia, 30 May, 2020, available at: https://asia.nikkei.com/Spotlight/Coronavirus/As-Japan-lags-in-coronavirustests-companies-to-triple-capacity, accessed on 1 March, 2021.

Kevin Fernandez, "Three Waves of Hate Speech Spreading Faster than the Pandemic in Malaysia: An Analyses of Outgroup Populist Narratives and Hate Speech during the COVID-19", GEOGRAFIA: Malaysian Journal of Society and Space, Vol. 16, No. 4, 2020, pp. 285-295.

Kimimasa Mayama, How Shinzo Abe has Fumbled Japan's Coronavirus Response, The Conversation, April 27, 2020, available at: https://theconversation.com/how-shinzo-abe-has-fumbled-japanscoronavirus-response-136860, accessed on 1 March, 2021.

Koichi Nakano, Japan Can't Handle the Coronavirus. Can It Host the Olympics?, The New York Times, 26 February, 2020, available at: https://www.nytimes.com/2020/02/26/opinion/coronavirus-japanabe.html, accessed on 1 March, 2021.

Kyodo, Experts Warn of Healthcare Collapse in Japan if Virus Keeps Spreading, The Japan Times, 2 April, 2020, available at: https://www.japantimes.co.jp/news/2020/04/02/national/health-carecollapse-warning-japan-coronavirus/, accessed on 1 March, 2021.

Linda Sieg, Where's Abe? Critics Ask, as Coronavirus Spreads in Japan, Reuters, 25 February, 2020, available at: https://www.reuters.com/article/us-china-health-japan-abe-idUSKCN20J16F, accessed on 1 March, 2021.

Lisa Schnirring, Japan has 1st Novel Coronavirus Case, Center for Infectious Disease Research and Policy, 16 January, 2020, available at: https://www.cidrap.umn.edu/news-perspective/2020/01/japanhas-1st-novel-coronavirus-case-china-reports-another-death, accessed on 1 March, 2021.

Lucy Gilson, "Everyday Politics and the Leadership of Health Policy Implementation", Health Systems \& Reform, Vol. 2, No. 3, 2016, pp. 187-193.

M. Uehara, M. Fuji, and K. Kobayashi, "A Model of Stress Change under the First COVID-19 Pandemic among the General Public in Japanese Major Cities and Rural Areas", Sustainability, Vol. 13, No. 3, 2021, available at: https://doi.org/10.3390/su13031207, accessed on 1 March, 2021.

Massimo Leone, "The Semiotics of the Anti-COVID-19 Mask: Evidence from Japan", Social Semiotics, Vol. 1, No. 1, 2020, pp. 40-70. 
Mathew Futterman, Hopes for Tokyo's Summer Olympics Darken, The New York Times, 15 January, 2021, available at: https://www.nytimes.com/2021/01/15/sports/olympics/tokyo-olympics.html, accessed on 1 March, 2021.

Matteo Chinazzi, Jessica T. Davis, Marco Ajelli, et al. "The Effect of Travel Restrictions on the Spread of the 2019 Novel Coronavirus (COVID-19) Outbreak", Science, Vol. 368, No. 6489, 2020, pp. 395400 .

Matthew Flinders, "Democracy and the Politics of Coronavirus: Trust, Blame and Understanding." Parliamentary Affairs, 2020, pp. 1-20, available at: https://doi.org/10.1093/pa/gsaa013, accessed on 1 March, 2021.

Mia R. K. Hartmann and Rasmus Koss Hartmann, "Frontline Innovation in Times of Crisis: Learning from the Corona Virus Pandemic", Policing, Vol. 14, No. 4, 2020, pp. 1092-1103.

Motoko Rich, Ben Dooley, and Makiko Inoue, Japan Shocks Parents by Moving to Close All Schools Over Coronavirus, The New York Times, 27 February, 2020, available at: https://www.nytimes.com/2020/02/27/world/asia/japan-schools-coronavirus.html, accessed on 1 March, 2021.

Motoko Rich, We're in a Petri Dish: How a Coronavirus Ravaged a Cruise Ship, The New York Times, 23 February, 2020, available at: https:/www.nytimes.com/2020/02/22/world/asia/coronavirus-japancruise-ship.html, accessed on 1 March, 2021.

Myo Nyein Aung, Motoyuki Yuasa, Yuka Koyanagi, and et al. "Sustainable Health Promotion for the Senior during COVID-19 Outbreak: A Lesson from Tokyo", The Journal of Infection in Developing Countries, Vol. 14, No. 4, 2020, pp. 328-331.

Nagisa Sugaya, Tetsuya Yamamoto, Naho Suzui, et al. "A Real-Time Survey of the Psychological Impact of Mild Lockdown for COVID-19 in the Japanese Population”, Scientific Data, Vol. 7, No. 1, 2020, pp.1-6.

National Institute of Infectious Disease (NIID), "Descriptive Epidemiology of 12 Confirmed Cases in Japan", NIID, 3 February, 2020, available at: https://www.niid.go.jp/niid/en/2019-ncov-e/2488idsc/iasr-news/9400-481pe01.html, accessed on 1 March, 2021.

Nikkei Staff Writers, Japan Extends Emergency Nationwide ahead of Golden Week, Nikkei Asia, 16 April, 2020, available at: https://asia.nikkei.com/Politics/Japan-extends-emergency-nationwideahead-of-Golden-Week, accessed on 1 March, 2021.

Nikkei Staff Writers, Japan's Coronavirus Testing behind the Curve, Abe Admits, Nikkei Asia, 5 May, 2020, available at: https://asia.nikkei.com/Spotlight/Coronavirus/Japan-s-coronavirus-testing-behindthe-curve-Abe-admits, accessed on 1 March, 2021.

Philip Bump, The Administration Keeps Bragging that U.S. Testing Now Is Better than South Korea's Was Months Ago, Washington Post, 12 May, 2020, available at: https://www.washingtonpost.com/politics/2020/05/11/administration-keeps-bragging-that-us-testingnow-is-better-than-south-koreas-was-months-ago/, accessed on 1 March, 2021. 
Rachel Bachman, A Tokyo Olympics Mystery: What Happens With 80,000 Volunteers During a Pandemic?, The Wall Street Journal, 4 March , 2021, available at: https://www.wsj.com/articles/tokyo-olympics-volunteers-pandemic-11614821947, accessed on 1 March, 2021.

Reiji Yoshida, and Satoshi Sugiyama, Abe Reaches Across isle for COVID-19 Emergency Law as Japan Cases Top 1,000, The Japan Times, 4 March, 2020, available at: https://www.japantimes.co.jp/news/2020/03/04/national/politics-diplomacy/abe-oppositioncoronavirus-emergency-law/, accessed on 1 March, 2021.

Reuters Staff, Japan to Disband Panel of Coronavirus Experts after Criticism, Reuters, 25 June, 2020, available at: https://www.reuters.com/article/us-health-coronavirus-japan-panel-idUSKBN23W0UY, accessed on 1 March, 2021.

Richard Carver, "Human Rights Practice in the Age of Pandemic", Journal of Human Rights Practice, Vol. 12, No. 2, 2020, pp. 247-249.

Rishi R. Parajuli, Bhogendra Mishra, Amrit Banstola, et al. "Multidisciplinary Approach to COVID19 Risk Communication: A Framework and Tool for Individual and Regional Risk Assessment", Scientific Reports, Vol. 10, No. 1, 2020, pp. 1-14.

Rocky Swift, Experts Warn Japanese Growing Complacent of Coronavirus Risk, Reuters, 24 March, 2020, available at: https://www.reuters.com/article/us-health-coronavirus-japan-expertsidUSKBN21B130, accessed on 1 March, 2021.

Ryusei Takahashi, Anxiety in Coronavirus in 2020 Spurs Unprecedented Societal Change in japan. Will It Last?, The Japan Times, 19 December, 2020, available at: https://www.japantimes.co.jp/news/2020/12/19/national/social-issues/2020-in-review-covid-19-

wrap/, accessed on 1 March, 2021

Sachiko Kodera, Essam A Rashed, and Akimasa Hirata. "Correlation between COVID-19 Morbidity and Mortality Rates in Japan and Local Population Density, Temperature, and Absolute Humidity", Environmental Research and Public Health, Vol. 17, 2020, pp. 1-15.

Sara E. Davies and Clare Wenham, "Why the COVID-19 Response Needs International Relations", International Affairs, Vol. 96, No. 5, 2020, pp. 1227-1251.

Satoshi Sugiyama, Japan Coronavirus Task Force may Set Stage of Emergency, The Japan Times, 26 March, 2020, available at: https://www.japantimes.co.jp/news/2020/03/26/national/sciencehealth/japan-coronavirus-task-force/ accessed on 1 March, 2021.

Satoshi Sugiyama, Japan State of Emergency to Cover Tokyo, Osaka and Five Other Prefectures, The Japan Times, 6 April 2020, available at: https://www.japantimes.co.jp/news/2020/04/06/national/japan-state-of-emergency-covid-19/, accessed on 1 March, 2021.

Satoshi Sugiyama, Suga Aims to Turn Page with Coronavirus Emergency Extension, The Japan Times, 2 February , 2021, available at: https://www.japantimes.co.jp/news/2021/02/02/national/sugaemergency-coronavirus-japan/, accessed on 1 March, 2021. 
Shimizu Kazuki and Negita Masashi, "Lessons Learned from Japan's Response to the First Wave of COVID-19: A Content Analysis", Healthcare, Vol. 8, No. 426, 2021, pp. 1-19.

Sho Saito, Yusuke Asai, Nobuaki Matsunaga, et al. "First and Second COVID-19 Waves in Japan: A Comparison of Disease Severity and Characteristics", Journal of Infection, Vol. November, 2020, pp. $1-3$.

Statista, Cumulative Number of Patients Diagnosed with Coronavirus Disease (COVID-19) in Japan, Statista, 15 January, 2021, available at: https://www.statista.com/statistics/1096478/japan-confirmedcases-of-coronavirus-by-state-of-health/, accessed on 1 March, 2021.

Suetgiin Soon, Chelsea C. Chou, and Shih-Jiunn Shi, "Withstanding the Plague: Institutional Resilence of the East Asian Welfare State", Social Policy \& Administration, Vol. 55, No. 1, 2021, pp. 374-387.

Susumu Cato, Takashi Iida, Asei Ito, et al. "The Bright and Dark Sides of Social Media Usage during the COVID-19 Pandemic: Survey Evidence from Japan", Reduction, Vol. 54, No. 2, 2020, available at: 10.1016/j.ijdrr.2020.102034, accessed on 1 March, 2021.

Syed Mahfuz Al hasan, Jennifer Saulam, Kanae Kanda, et al. "Trends in COVID-19 Outbreak in Tokyo and Osaka from January 25 to May 6 2020: A Joinpoint Regression Analysis of the Outbreak Data", Japanese Journal of Infectious Disease, Vol. 74, No. 1, 2020, pp. 73-75.

Takashi Yoshioka, and Yohei Maeda, "COVID-19 Stigma Induced by Local Government and Media Reporting in Japan: It's Time to Reconsider Risk Communication Lessons From the Fukushima Daiichi Nuclear Disaster", Journal of Epidemiology, Vol. 30, No. 8, 2020, pp. 372-373.

Takuya Mizorogi, Japan's Suga Slips to 42\% Approval Rating in New Nikkei Poll, Nikkei Asia, 28 December, 2020, available at: https://asia.nikkei.com/Politics/Japan-s-Suga-slips-to-42-approvalrating-in-new-Nikkei-poll, accessed on 1 March, 2021.

Tetsushi Kajimoto, Japan's Suga Hopes to Suceed PM Abe, Race Heats Up, Reuters, 30 August, 2020, available at: https://www.reuters.com/article/us-japan-politics-idUSKBN25Q03M, accessed on 1 March, 2021.

The Illness Now Has a Name, COVID-19, New York Times, 11 February, 2020, available at: https://www.nytimes.com/2020/02/11/world/asia/coronavirus-china.html, accessed on 1 March, 2021. Tolbert Nyenswah, "Leadership in Times of Crisis: A Personal Reflection from the Center of the Ebola Epidemic Response in Liberia”, Health Systems \& Reform, Vol. 2, No. 3, 2016, pp. 208-2012.

Valentina Giammaria, "COVID-19 in Japan: A Nightmare Disease", Asia Pacific Journal-Japan Focus, Vol. 18, No. 18, 2020, pp. 1-10.

Van Tuan Hoang, Jaffar A. Al Tawfiq, and Philippe Gautret, "The Tokyo Olympic Games and the Risk of COVID-19", Current Tropical Medicine Report, Vol. 7, 2020, available at: 10.1007/s40475020-00217-y, accessed on 1 March, 2021.

Victor Mathew, and Motoko Rich, Despite Virus Surge, I.O.C. Pledges Summer Olympics in Tokyo Will Happen, The New York Times, 21 January, 2021, available at: https://www.nytimes.com/2021/01/21/sports/olympics/bach-olympics-tokyocovid.html\#: :text=the\%20main\%20story- 
,Despite\%20Virus\%20Surge\%2C\%20I.O.C.,Olympics\%20in\%20Tokyo\%20Will\%20Happen\&text= \%E2\%80\%9CWe\%20have\%2C\%20at\%20this\%20moment, \%2C\%E2\%80\%9D\%20Bach\%20told\%2 0Kyodo\%20News., accessed on 1 March, 2021.

Vivian Wang, As Death Mounts, Governments Point Fingers Over Coronavirus, The New York Times, 6 March, 2020, available at: https://www.nytimes.com/2020/03/06/world/coronavirus-world.html accessed on 1 March, 2021.

Will Repley, There are Fears a Coronavirus Crisis Looms in Tokyo. Is It Too Late to Change Course?, CNN, 4 April, 2020, available at: https://edition.cnn.com/2020/04/03/asia/tokyo-coronavirus-japanhnk-intl/index.html, accessed on 1 March, 2021.

William Sposato, Japan and Korea Won't Let A Pandemic Stop Them Fighting, Foreign Policy, 12 March, 2020, available at: https://foreignpolicy.com/2020/03/12/japan-and-korea-wont-let-apandemic-stop-them-fighting/, accessed on 1 March, 2021.

World Health Organization (WHO), "Japan: WHO Coronavirus Disease (COVID-19) Dashboard", WHO, March 3, 2021, available at: : https://covid19.who.int/region/wpro/country/jp, accessed on 1 March, 2021.

World Health Organization (WHO), COVID-19 Weekly Epidemiological Update, WHO, February 28, 2021, available at: https://www.who.int/publications/m/item/weekly-epidemiological-update-oncovid-19---31-march-2021, accessed on 1 March, 2021.

Xiaochen Su, Lack of Transparency Complicates Japan's Handling of COIVD-19, The Diplomat, 6 February, 2021, available at: https://thediplomat.com/2021/02/lack-of-transparency-complicatesjapans-handling-of-covid-19/, accessed on 1 March, 2021.

Yexin Mao, "Combating COVID-19 Through Collaborative Governance: Lessons from East Asia", Chinese Public Administration Review, Vol. 11, No. 2, 2020, pp. 132-141.

Yoko Konishi, Takashi Saito, Toshiki Ishikawa, et al. "How did Japan Cope with COVID-19? Big Data and Purchasing Behaviour", Asian Economic Papers, Vol. 2, No. 1, 2020, pp. 1-20. 